\title{
A tudástermelési függvénytől a fejlesztéspolitikai hatáselemzésig
}

\begin{abstract}
Akadémiai székfoglaló előadásában a szerző - a kezdetektől a legfrissebb elemzésekig - végigköveti az elmúlt két évtized során kutatócsoportjaival kidolgozott földrajzi, makro- és regionális (Geographic, Macro and Regional, GMR) hatáselemző modellrendszer kifejlődését. A GMR modelleket számos esetben alkalmazták hazai és európai uniós vizsgálatokban a kohéziós politika, az innovációalapú fejlesztéspolitikák vagy a vállalkozásösztönzés regionális, nemzeti és EU-szintű hatásainak megbecslésére. A hatásokat többek között a GDP-re, a gazdasági növekedésre, a foglalkoztatottságra vagy a régiók közötti egyenlőtlenségek alakulására számítják ki. A GMR modellek sajátossága az, hogy (a nemzetközi gyakorlatban is egyedülállóan) mind regionális, mind nemzeti (és nemzetek feletti) szinten megbecsülik a hatásokat úgy, hogy a földrajzi tényezőket (szállítási költséget, agglomerációs hatásokat, régióközi migrációt, interregionális kereskedelmet, térbeli tudás-továbbterjedést) is beépítik az elemzésekbe. A szerző - követve a székfoglaló előadásban elhangzottakat - a GMR modellek elméleti alapjainak bemutatása után az integrált regionális és makrogazdasági hatás modellezésének kihívásait határozza meg, valamint azt, hogy a GMR modellek miként válaszolnak e kihívásokra. Végül a modellek képességeinek illusztrálására néhány, a közelmúltban készült intelligens szakosodási szimulációt ismertet.* Journal of Economic Literature (JEL) kód: C63, L26, M13, O10, R58.
\end{abstract}

* A tanulmány a szerző 2019. szeptember 26-án elhangzott akadémiai székfoglalójának írásos változata.

A tanulmány megírásában segítségemre volt az Európai Unió, Magyarország és az Európai Szociális Alap által társfinanszírozott, EFOP-3.6.2-16-2017-00017-es azonosító számú „Fenntartható, intelligens és befogadó regionális és városi modellek" projekt.

Ezúttal fejezem ki köszönetemet azoknak a magyar és külföldi munkatársaimnak, akikkel az utóbbi közel két évtized során együtt dolgoztam a GMR modellek fejlesztésein és szakpolitikai alkalmazásain. Név szerinti sorrendben: Abaligeti Gallusz, Mete Basar Baypinar, Béres Attila, Ember László, Erdös Katalin, Farkas Richárd, Galambosné Tiszberger Mónika, Hau-Horváth Orsolya, Horváth Márton, Járosi Péter, Juczi Kata, Randall Jackson, Atsushi Koike, Longauer Dóra, Habuda Judit, Hajdu Szilvia, Monigl János, Kehl Dániel, Polónyi-Andor Krisztina, Révész Tamás, Hans Joachim Schalk, Sebestyén Tamás, Somogyiné Komlósi Éva, Szabó Norbert, Szerb László, Lori Tavasszy, Tétényi Tamás, Mark Thissen, Hannu Thörma, Varga-Csajkás Anna, Vida Szabolcs.

Varga Attila, Regionális Innováció- és Vállalkozáskutató Központ (RIERC) Közgazdaságtan és Ökonometria Intézet, MTA-PTE Innováció és Gazdasági Növekedés Kutatócsoport, Pécsi Tudományegyetem Közgazdaságtudományi Kar.

A kézirat első változata 2020. április 13-án érkezett szerkesztőségünkbe.

DOI: http://dx.doi.org/10.18414/KSZ.2020.6.537 


\section{Bevezető}

Akadémiai székfoglaló előadásomban a kutatócsoportjaimmal az utóbbi több mint másfél évtized során kifejlesztett, nemzetközileg is számottevő figyelmet élvező fejlesztéspolitikai hatásmodellezési irányzat eredetét és főbb eredményeit mutattam be. A földrajzi, makro- és regionális (Geographic, Macro and Regional, GMR) modellrendszer gyökerei az Egyesült Államokban az 1990-es években végzett tudástermelési függvényre alapozott PhD-kutatásaimban találhatók (Varga [1998]). Párhuzamosan doktori tanulmányaimmal kutatási asszisztensként évekig dolgoztam gazdasági elörejelzésekre kifejlesztett regionális modellekkel. E kétirányú tapasztalás és a hazai szakpolitika irányából a 2000-es évek elején érkezett, modellfejlesztést célzó megkeresés indította el a GMR rendszer megszületését.

A Nemzetek jólétében Adam Smith így fogalmaz:

„A közgazdaságtan úgy tekinthető, mint az államférfi vagy törvényhozó tudományának egyik ága, melynek két különböző célja van. Először: hogy a népességnek bőséges jövedelmet vagy megélhetést biztosítson, vagy helyesebben, hogy lehetővé tegye számára ilyen jövedelem és megélhetés biztosítását; és másodszor, hogy az államot vagy közületet a közszolgáltatások teljesítéséhez elégséges jövedelemmel lássa el.” (Smith [1940] I. kötet, 420. o.)

A közgazdasági elméletek gazdasági modellekben való gyakorlati alkalmazása révén jut a közgazdaság-tudomány talán a legközelebb ahhoz a feladathoz, amelyet Adam Smith, mai fogalmazással élve, a gazdaságpolitikai döntések támogatásaként jelölt meg a fenti idézetben. A hatáselemző modellek használata által a döntéshozók fontos információhoz juthatnak a gazdaságpolitikai beavatkozások (mint például a költségvetési vagy monetáris politikai vagy a fejlesztéspolitikai intervenciók) hatásairól számos fontos változó (a GDP, a munkanélküliség, az infláció vagy a területi egyenlőtlenségek) alakulására.

A fejlesztéspolitika a gazdasági növekedés ösztönzését célozza olyan beavatkozásokkal, mint a vállalati beruházások támogatása, az infrastruktúra fejlesztése, az emberi tőke és az innováció támogatása vagy a vállalkozási kapacitások fejlesztése. A fejlesztéspolitikai beavatkozások hatásainak vizsgálata leggyakrabban gazdasági modellekkel történik. Az EU kohéziós politikájának hatáselemzésére használt modellek például a fenti beavatkozások hatásaira végeznek becsléseket (Ratto és szerzötársai [2009]). A gazdasági modellek többségükben nemzeti (makro-) szinten elemzik a hatásokat. A fejlesztéspolitikai hatáselemzésekben gyakran használt makromodellek tehát aggregált modellek, vagyis a beavatkozások hatásait nézik az országos GDP-re, a foglalkoztatásra vagy az árszínvonalra.

A gazdasági hatáselemzés hagyományos, nemzeti szinten aggregált modelljei egyre kevéssé képesek megfelelni azoknak a kihívásoknak, amelyeket a fejlesztéspolitika legutóbb megjelent irányzatai támasztanak. A legfrissebb innovációs politikai irányzatokban (például az EU intelligens szakosodási politikájában) előtérbe kerültek a nemzeti szint alatti területi egységek (a régiók). A szakpolitikai beavatkozások pedig kiválasztott iparágak fejlesztésén keresztül kívánják a régiók 
növekedését ösztönözni. A fenti beavatkozások mellett újabbak is megjelentek a fejlesztéspolitika gyakorlatában: a vállalkozásfejlesztés és az innovációs kapcsolatok ösztönzése. Azok a modellek tehát, amelyek nemzeti szinten és aggregáltan kezelik a gazdaságot, nem képesek a regionális innováció és fejlődés, a vállalkozás- és innovációs hálózati fejlesztés vagy az iparági növekedés modern problémáit kezelni (Varga és szerzötársai [2020a], [2020c]).

Előadásomban egy további kihívással foglalkoztam mélyebben, egy olyan kihívással, amely abból következik, hogy a térbeliség mind a közgazdaságtanban, mind a fejlesztéspolitika elméletében hangsúlyossá vált az utóbbi évtizedekben. A fejlesztéspolitika modern irányzatainak tanulsága az, hogy egy nagyobb területi egység (egy ország vagy az országok integrációja) fejlesztésénél nem szabad figyelmen kívül hagyni, hogy a konkrét beavatkozások mindig a tér valamely pontján történnek, és ezen beavatkozások hatékonyságát a térbeli hatások (mint például az agglomerációs hatások, az innováció régiónként változó adottságai vagy a régiók közötti kapcsolatrendszerek) jelentősen befolyásolják. Ezért ugyanaz az országos szintű fejlesztéspolitikai költségvetés a nemzeti és regionális növekedést eltérően befolyásolja, attól függően, hogy miként valósul meg az erőforrások régiók közötti elosztása.

Azok a modellek, amelyek országos szinten elemzik a hatásokat, nem képesek megragadni a beavatkozások térbeliségét, ezért olyan modellek kifejlesztésére van szükség, amelyek a térbeliséget érzékelik. Az előadásom középpontjában szereplő GMR gazdasági modellek ezekre a kihívásokra válaszolva kerültek kidolgozásra. Székfoglalómban a területiséggel kapcsolatos kihívásokat elemeztem, és ebben a kontextusban ismertettem a GMR modelleket. A tér integrálásával kapcsolatos modellezési kihívásokat fogalmazom meg a következö fejezetben, majd két fejezetben mutatom be, hogy a GMR modellrendszer miként válaszol ezekre a kihívásokra. Az ezt követő fejezet szakpolitikai szimulációi illusztrálják a GMR modellekben rejlö lehetőségeket. Összegzés zárja a tanulmányt.

\section{A modern regionális fejlesztéspolitikai modellezés kihívása - a tér integrálása ${ }^{1}$}

A közgazdaságtan dominánsan tér nélküli szemlélete az utóbbi negyedszázad folyamán fokozatos változásokon megy keresztül, döntően az új gazdaságföldrajz megjelenésének és térhódításának következményeként. A statikus új gazdaságföldrajzi modellek egy hagyományos, tér nélküli gazdaságmodellt tesznek többrégióssá, ezáltal integrálják a szállítási költségeket, a régiómérettel összefüggő agglomerációs hatásokat és a termelési tényezők régiók közötti migrációját (Krugman [1991], Fujita és szerzőtársai [1999]). A dinamikus új gazdaságföldrajzi modellek pedig az agglomerációs hatásokat építik be az eredetileg tér nélküli növekedési modellekbe (Baldwin-Martin [2004]). Az így felépített statikus és dinamikus

\footnotetext{
${ }^{1}$ A 2., 3. és 4. fejezetek megírása során több ponton építkeztem a Varga [2016], [2017] és [2019] tanulmányokban megfogalmazottakra.
} 
modellek rávilágítanak arra, hogy egy ország vagy egy még nagyobb területű gazdasági integráció gazdaságföldrajza (vagyis a gazdasági tevékenységek térbeli elhelyezkedése) meghatározó szerepet játszik a makroszintü eredményekben (GDP, foglalkoztatás, növekedés) (Varga [2009]).

A gazdasági tevékenységek térbeli elhelyezkedésének a nemzetek fejlődésében játszott szerepére az utóbbi évtized szakpolitikai vitái is rámutatnak (World Bank [2009], OECD [2009], Barca [2009]). Mind a területalapú, mind a térsemleges beavatkozásokat pártoló irányzat, eltérő hangsúlyokkal ugyan, de egyetért abban, hogy olyan gazdaságföldrajzi jellemzők, mint a térbeli külső méretgazdaságosság (agglomerációs előnyök vagy hátrányok), az országokon belüli régiók gazdasági lehetőségei vagy a gazdasági szereplők régiókon belüli és régiók közötti interakciói, meghatározók a gazdaságfejlesztést célzó szakpolitikai beavatkozások sikerében. Különböző makroszintü (nemzeti szintű) eredményekhez vezethet ugyanis egy ország gazdaságfejlesztését célzó költségvetése attól függően például, hogy a nagy agglomerációk fejlesztésére vagy a lemaradó területek támogatására fordítják. A beavatkozások földrajza tehát meghatározó eleme a fejlesztéspolitika sikerének. A makro- és regionális (a nemzeti és a nemzeti szint alatti) területi egységek közötti interakciók további fontos elemére mutatnak rá az utóbbi évek kutatásai (D'Costa és szerzőtársai [2013]). A makroszinten meghatározott gazdaságpolitikák (például a monetáris és fiskális politikák) szignifikánsan befolyásolhatják ugyanis a regionális fejlesztéspolitikai beavatkozások sikerét: támogathatják, de akár vissza is foghatják azok eredményességét.

A legújabb közgazdaság-elméleti eredmények és a fejlesztéspolitikai diskurzusok tehát rámutatnak arra, hogy a makro- és a regionális szintek kölcsönösen összefüggenek a fejlődésben: a beavatkozások térbeli eloszlása befolyásolja a makroszintü eredményeket, de a regionálisan megvalósított beavatkozások hatásai sem függetlenek a makroszintü gazdaságpolitikai intézkedésektől. Annak ellenére, hogy az elméletben és a szakpolitikai vitákban már felismerték a makro- és regionális dimenziók jelentőségét és interakcióit, a gazdaságfejlesztés hatásainak vizsgálatában gyakran használt gazdasági modellek továbbra is külön kezelik e két szintet. A modellek² döntően a nemzeti szintü (GDP, foglalkoztatás, növekedés stb.) hatásokat elemzik.

Amennyiben tehát a gazdaságmodellezés jelenlegi uralkodó vonulatát követjük, és egy nagyobb területi egység (egy ország vagy annál magasabb integráció) gazdaságfejlesztését célzó beavatkozások hatáselemzéseit makrogazdasági (nemzeti vagy nemzetek feletti szinten aggregált) modellekkel vizsgáljuk, az összefüggések egy igen lényeges oldala, a térbeli hatások rendszere marad ki a képből. A beavatkozás (szubnacionális) régiójában alkalmazott eszközeinek hatását ugyanis megnövelhetik vagy éppen lecsökkenthetik a régióspecifikus pozitív vagy negatív agglomerációs hatások, az oda- és elvándorlás, a regionálisan változó interregionális tudásáramlás-erősség vagy az adott régió ágazati szerkezete. Ezekre a hatásokra a nagyobb területi egységeket egy pontként kezelő makrogazdasági modellek viszont érzéketlenek.

\footnotetext{
${ }^{2}$ A HERMIN modell (ESRI [2002]), az ECOMOD modell (Bayar [2007]) vagy a QUEST III modell (Ratto és szerzőtársai [2009]) jó példák a makroökonómiai modellekre.
} 
Tehát minden beavatkozás térspecifikus, és a modell alkotójának arra kell törekednie, hogy ezt a térspecifikusságot minél pontosabban be tudja építeni a modell struktúrájába, hiszen azok csak ekképpen lesznek képesek a különböző szakpolitikai beavatkozások eredményeit nyomon követni, és így a politikák előzetes és utólagos hatásvizsgálatában információval szolgálni. A tér gazdaságmodellezési integrálása viszont nem kihívások nélküli feladat. A következőkben a térszemléletű gazdaságmodellezés előtt álló legfontosabb kihívásokat ismertetem. Idetartozik a technológiai fejlődést ösztönző politika hatásainak modellbe foglalása, az innovációs hatásoknak a gazdasági változókban (GDP, foglalkoztatás, árak stb.) való megjelenítése, az idö- és térbeli dinamika szimultán modellezése és a makroökonómiai szint integrálása a regionális modellkörnyezetbe.

\section{Az innovációpolitikai hatások modellezése}

A modern kori növekedés elismerten legfontosabb inputja a technológiai fejlődés. Ezzel összhangban a legújabb fejlesztéspolitikai irányzatok is az innováció regionális ösztönzésének szükségességét hangsúlyozzák. Az első lépés tehát a modellezésben arra vonatkozik, hogy miként építsük be a modell kereteibe a szakpolitikai instrumentumok innovációra való hatását. Igen gazdag empirikus irodalom dolgozza fel az innováció földrajzi vonatkozásait (Varga-Horváth [2015]), és ezáltal lényeges információk állnak rendelkezésre a modellek építői számára.

A szakirodalom rámutat arra, hogy az akadémiai intézmények (egyetemek, közösségi finanszírozású kutatóintézetek) és innovatív vállalatok, illetve vállalati $\mathrm{K}+\mathrm{F}$-laboratóriumok közötti helyi tudásáramlás pozitív kapcsolatban áll a regionális innováció szintjével (Feldman-Florida [1994]). Mindezeken túl, a tudástranszfer gyakran átlépi a régióhatárokat. Az empirikus kutatások szerint a helyi tudásáramlás erőssége a távolsággal folyamatosan csökken (Anselin és szerzőtársai [1997]). A szakirodalmi eredmények azt is alátámasztják, hogy a régió vállalkozási szintje is hat az innováció és a kutatás-fejlesztés közötti kapcsolatokra (Acs-Varga [2005]). További, a gazdaságmodellezés szempontjából fontos információ az is, hogy az innovációban részt vevő szereplők ,agglomerálódása” (versenyző és beszállító vállalatok, üzleti szolgáltatók, akadémiai és magán-kutatólaboratóriumok térbeli tömörülése) is pozitív összefüggést mutat a regionális innováció nagyságával (Varga [2000]). Az intézmények szerepe a helyi tudástermelési folyamatban szintén nem elhanyagolandó tényező, ahogyan erre a szakirodalom szintén hangsúlyosan rámutat (Boschma [2005]).

Az innovációnak a regionális kutatás-fejlesztéssel és az emberi tőkével, a fizikai közelséggel, az agglomerációval, a vállalkozással és a tudáshálózatokkal megfigyelt pozitív kapcsolata megalapozza a modern szakpolitikai irányzatokban megjelent elgondolásokat. E megközelítések olyan integrált szakpolitikákat céloznak, amelyek a K +F-ösztönzést, az oktatásfejlesztést, a vállalkozási környezet javítását, a megközelíthetőséget célzó infrastrukturális beruházásokat és a kutatási együttmüködések elősegítését tartalmazzák, reálisan feltételezve, hogy ezek a támogatások élénkíteni fogják az innovációs aktivitást. 
Visszatérve a gazdaságmodellezési kihívásokhoz, és tudomásul véve a fenti szakpolitikai stratégiák relevanciáját, továbbra is kérdéses, hogy a helyi innovációt meghatározó komplex környezeti feltételrendszer miként ültethető át a hatáselemző modellek nyelvére. A már most kidolgozott lehetőségek közül felmerülhet a térbeli tudástermelési függvény alkalmazása (Varga és szerzőtársai [2014]), a regionális számszerüsített általános egyensúlyi (Computable General Equilibrium, CGE) modellek építése (Hermannsson és szerzőtársai [2010]) vagy a dinamikus evolúciós modell megközelítése (Fagiolo-Dosi [2003]).

\section{A technológiai hatás gazdasági változókkal való kapcsolatának modellezése}

A válasz arra a kérdésre, hogy miként kapcsoljuk a szakpolitika innovációs hatását a gazdasági változókhoz (output, foglalkoztatás vagy infláció), nem magától értetődő. Az innováció aggregált növekedési hatása két (nem feltétlenül egymást kizáró) úton történik. A technológiai fejlődés vagy a már előállított termékek számát növeli (termelékenységi hatás), vagy új termékek bevezetését eredményezi (változatossági hatás) (Saviotti-Pyka [2003]). Mind a termelékenységi, mind a változatossági hatások modellezése kihívásokkal teli feladat.

A gazdasági növekedés elméletei különböző megoldásokat javasolnak. Bár a Romer [1990] által megalapozott endogén modell szerint az innováció új változatokat produkál, a modellben a végső javak aggregált jellege elfedi az új termékek közötti változatosságot, így igazából az outputnövekedés termelékenységnövekedésként jelenik meg. Az Aghion-Howitt [1998] által felírt többszektoros növekedési modell ugyan lehetővé teszi a szektorok közötti áramlásokat, de a szektorok száma a modellben konstans, így a változatossági hatás itt is korlátozott. A neoklasszikus irányzattal összevetve a schumpeteri evolúciós növekedési elméletekben, amelyekhez Fagiolo-Dosi [2003] vagy Saviotti-Pyka [2003] munkái kötődnek, a változatossági hatás megoldása sikeresebbnek tünik.

Mindazonáltal itt is érvényes az, amit bármely teoretikus rendszerrel kapcsolatban megállapít az empirikus gazdaságmodellező: számos technikai gond nehezíti az elméleti tételek gyakorlati modellekbe való átültetését, amelyek közül az adatok elöfordulása, különösen a szubnacionális régiók szintjén, az egyik igen súlyos probléma.

\section{A növekedés tér-idö dinamikájának modellezése}

Az innovációt ösztönző beavatkozások hozzájárulnak a regionális gazdasági növekedéshez, ha az új termékek/termékváltozatok iránti kereslet növekszik (változatossági hatás), vagy ha a kereslet növekedése túlkompenzálja az egységköltség-növekedést (termelékenységi hatás). Egy adott nemzeti fejlesztéspolitikai költségvetés a növekedésre hathat, részben közvetlenül: a regionális erőforrások (technológia, munka, tőke) bővítésének ösztönzésével; valamint részben közvetetten, azáltal, hogy a regionális beavatkozás tényezőáramlást indukálhat a többi régióból. 
A növekedésösztönzés tér-idő dinamikája tehát azt jelenti, hogy a termelés tényezői szimultán módon növekednek a helyi források bevonásával és a más régiókból való bevándorlással. A fejlesztéspolitikai hatások modellezésének tehát tartalmaznia kell a növekedés tér-idő dinamizmusának integrálását. A kihívás itt a belső források növekedésének és a termelési tényezők térszerkezet-változásának szimultán modellezése. Különböző területi/instrumentális támogatási kombinációk különböző tér-idő növekedési dinamikát eredményezhetnek. E komplex folyamat követésére a regionális modellek rendszere lehet alkalmas, ahol a régiókat a kereskedelmi, migrációs és technológiaáramlási folyamatok kapcsolják össze. Ennek a folyamatnak a modellezése több technikai kérdést felvető feladat.

Az egyik kihívás a regionális modellek típusának megválasztása. A leggyakrabban a regionális ökonometriai modelleket (Capello [2007]), illetve a regionális számszerüsített általános egyensúlyi (Computable General Equilibrium, CGE) modelleket (Partridge-Rickman [2010]) használják. A modellek közötti fontos különbségek még a piaci szerkezetben (tökéletes vagy tökéletlen verseny), a munkaerő-migráció motivációinak (interregionális bérkülönbségek vagy régióközi hasznosságbeli különbségek), vagy a különböző agglomerációs hatásoknak (pénzben kifejezhető vagy technológiai externáliák) a meghatározásában állnak.

A tér-idő dinamika modellezése során tudnunk kell együttesen követni a belső erőforrások szakpolitika által indukált növekedését és a következményként adódó régiók közötti erőforrásmozgást. A neoklasszikus növekedési kerettel való konzisztencia azt követelné, hogy a háztartások és a vállalatok megtakarítási és beruházási döntéseinek optimalizálása egy komplex tér-idő rendszerben legyen megfogalmazva, ahol az optimalizálás a jövőbeli térbeli pozíciók változását is magában foglalja. Mindez az - egyetlen egységes piacot feltételező - egypont-gazdaság jellegü makroökonómiai modellek önmagukban sem egyszerű megoldásait a szimultán tér-idő mozgásokkal bonyolítja. A modellek ez irányú fejlődése igen lassú, ami az analitikai és számítási nehézségek együttes jelenlétéből következik (BröckerKorzhenevych [2011]).

Alternatív megoldásként adódik valamely többé-kevésbé ad hoc beruházási és megtakarítási magatartás beépítése a regionális modellekbe (Ivanova és szerzőtársai [2007]) vagy a neoklasszikus rendszerrel konzisztens beruházási és megtakarítási viselkedés modellezése egy makromodellben, valamint a migráció és a dinamikus agglomerációs hatások beépítése a regionális modellekbe egy integrált modellrendszer keretében, ahogyan ezt a GMR modellek teszik (Varga [2017]).

\section{A makrogazdasági hatások beépitése}

A makrogazdasági feltételek - mint például a nemzeti valuta árfolyama, a kormányzati deficit, a monetáris politika vagy a kamatlábak - lényeges tényezők lehetnek a fejlesztéspolitika hatásosságának alakulásában. Egy ideálisan megtervezett szakpolitika kidolgozásakor a gazdasági fejlesztést összehangolják a makrogazdasági keretfeltételekkel. Mivel a makrogazdasági keretfeltételek regionális szintről való 
levezetésének elmélete nem áll rendelkezésre (és ami a legvalószínűbb: ezen feltételek területi aggregálása feltehetően nem is lehetséges), ezért az önállóan modellezett makroszint integrálása a regionális modellrendszerbe elfogadható megoldásnak tünik. Ez a kérdéskör a kutatás nyitott területe, így a megoldások még mindig ritkák a szakirodalomban (Varga [2016]).

\section{A GMR gazdaságmodellezési irányzat}

A szakpolitikai hatáselemzésekben a GMR gazdaságmodellezési irányzat újdonsága a makroökonómiai modellekhez viszonyítva tipikusan az, hogy a modell szerkezetébe integrálja a teret, ami által közvetlenül megfigyelhetőkké válnak a térbeli tudásáramlások, az agglomerációs hatások vagy az interregionális kereskedelem és a migráció következményei. A modellek térbeli közelítéséből eredő további újdonság az, hogy nemcsak a makroökonómiai, de a regionális hatások is követhetők.

A GMR modellezési irányzat a közgazdaságtan különböző tradícióiban gyökerezik (Varga [2016]). Míg a GMR irányzat a térbeli tudásáramlás és agglomerációs hatásainak modellezése során az innováció-földrajz szakirodalmában kifejlesztett módszerekre épít (Anselin és szerzőtársai [1997], Varga [2000]), addig az interregionális kereskedelem és migráció, valamint a dinamikus agglomerációs hatások modellezésekor felépített empirikus általános egyensúlyi modell az új gazdaságföldrajz talaján áll (Krugman [1991], Fujita és szerzőtársai [1999]). A makroökonómiai összefüggések megragadása pedig a megfelelő makroökonómiai elméletek felhasználása révén történik.

A GMR modellezési irányzatot és annak közgazdaságtani gyökereit részletesen Varga [2016] mutatja be. A GMR modelleket számos kollégával való együttmüködéseim során dolgoztuk ki. A modellezési irányzat első megvalósulása a Nemzeti Fejlesztési Hivatal számára megalkotott és az 1. Nemzeti Fejlesztési Terv (2004-2006) hatáselemzésére alkalmazott EcoRET modell (Schalk-Varga [2004]). Az EcoRET modell továbbfejlesztései során született meg a GMR-Magyarország modell több változata (Varga és szerzőtársai [2013], [2020b]). Az EU 7. keretprogram és a H2020-as projekt finanszírozta a GMR-Európa (Varga [2017], Varga és szerzötársai [2018]) és a GMR-Törökország (Varga-Baypinar [2016]) modelleket. Ezek felhasználásával szintén számos szakpolitikai elemzés született.

Miért lényeges a földrajzi dimenzió szerepeltetése a fejlesztéspolitikai hatáselemzésben? Miért nevezzük a modellt egyszerre „makro-” és „regionális” modellnek? A térbeli elhelyezkedés legalább négy szempontból játszik meghatározó szerepet a fejlesztéspolitikai beavatkozások eredményességében (Varga [2006]). Elöször is, minden beavatkozás a tér egy adott pontjában történik, és a hatásai onnan terjedhetnek tovább távolabbi pontokba. Másodszor, az induló effektus a pozitív vagy negatív külső méretgazdaságossági (agglomerációs) hatások eredményeképpen megsokszorozódhat, vagy akár kissebbé is válhat, már viszonylag rövid távon is. Harmadszor, a beavatkozás következtében esetlegesen kiváltott munkaerő- és tőkeáramlás tovább növelheti vagy csökkentheti a kiinduló hatásokat, amelyek 
révén a gazdaság térszerkezete is átrendeződhet (dinamikus agglomerációs hatások). Negyedszer, az elöbbi földrajzi hatások következtében ugyanolyan értékű és szerkezetü fejlesztéspolitikai beavatkozások (eltérö térbeli eloszlásaik révén) eltérő makroökonómiai eredményeket vonnak maguk után. Ezen különbözö eredmények kimutatására a tér nélküli, hagyományos modellek nem képesek, következésképpen az általuk adott hatások torzítottak lesznek.

A „régió” földrajzi referenciapont a GMR modellekben. Olyan térbeli egység, amely a nemzeti szintnél alacsonyabb aggregációt jelent, és alkalmas az innovációt mozgató közelségi kapcsolatok megjelentetésére. Az intraregionális interakciók mellett a modell az interregionális interakciókat is számításba veszi, idetartozik a régióhatárokat átlépő tudásáramlás, a régiók közötti kereskedelem vagy a munkaerő- és tőkeáramlás.

A „makroszint” ugyancsak fontos a fejlesztéspolitikai hatások modellezése szempontjából: a költségvetési vagy a monetáris politika intézkedései, a nemzeti szintű szabályozások vagy a nemzetközi hatások szintén potenciálisan releváns tényezők ebböl a szempontból. A modell a beavatkozásoknak mind a makro-, mind a regionális szintủ eredményeire elkészíti a becsléseket, és lehetővé teszi különböző forgatókönyvek makro- és regionális gazdasági hatásainak összehasonlítását.

\section{A tér integrálása a GMR modellekben}

A GMR-Európa modell (Varga és szerzőtársai [2018]) példáján keresztül mutatom be, hogy a modellrendszer miként reflektál A modern regionális fejlesztéspolitikai modellezés kihívása - a tér integrálása című fejezetben felsorolt kihívásokra. A GMR modellek három részmodellt integrálnak, három blokkba szervezve: a regionális termelékenységi (TFP), a regionális térbeli számszerűsített egyensúlyi (SCGE) és a makroökonómiai (MACRO) blokkokba. A modell az EU 181 NUTS 2-es régióját foglalja magában.

\section{A TFP blokk}

A GMR modellek az első számú modellezési kihívásra („az innovációpolitikai hatások modellezése") a TFP blokk megépítése révén adják meg a választ. Az 1. ábra illusztrálja a GMR-Európa modell TFP blokkjának felépítését. A TFP blokk a GMR modellrendszer kulcsváltozóit tartalmazza, és a tudástermelési függvény Romer [1990] által megalkotott változatára épül.

A blokk két egyenletet tartalmaz: a regionális szabadalmi és a regionális TFPegyenleteket. A szabadalmak számát a K + F-kiadások, az EU-keretprogramok által finanszírozott kutatói hálózatokban elfoglalt pozíció (amelyet az ENQ indexszel ${ }^{3}$ mérünk), a régiómérettel becsült agglomerációs hatások (amit a foglalkoztatottak

\footnotetext{
${ }^{3}$ A hálózatokon keresztül elérhető tudás mérésére szolgál az egohálózat-minőség (Ego Network Quality, ENQ) index (Sebestyén-Varga [2013]).
} 
1. ábra

A TFP blokk felépítése

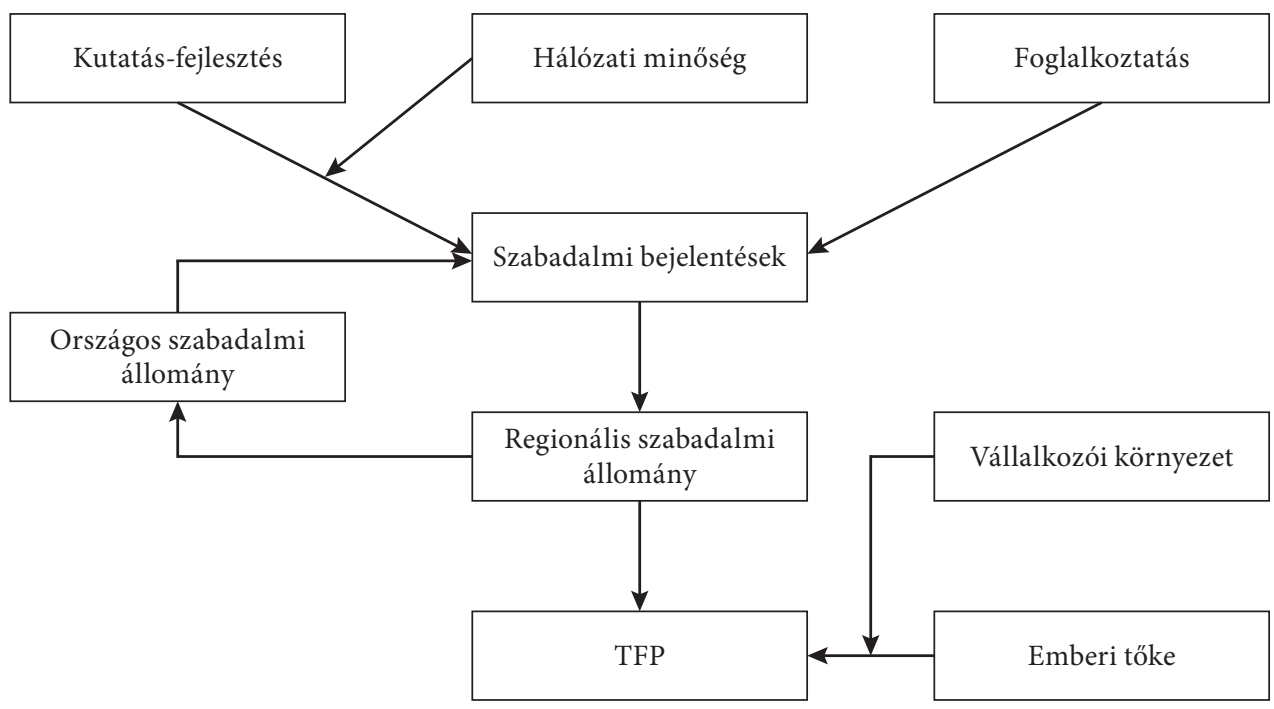

száma mér) és az országos szinten felhalmozott tudást mérő szabadalmi állomány határozza meg. A TFP-t pedig a régió emberitőke-állománya, vállalkozási szintje (melyet a REDI indexszel ${ }^{4}$ mérünk) és a regionális szabadalmi állomány szabja meg. A paraméterek ökonometriai becslése szolgál annak a kalibrálási folyamatnak az alapjául, amelynek során minden egyes, a mintában szereplö régióra ráillesztjük a TFP blokkot alkotó egyenletrendszert, mégpedig azokkal a paraméterekkel, amelyek a legprecízebb módon adják vissza a régiók adatait.

\section{A regionális térbeli számszerüsített egyensúlyi (SCGE) blokk}

A második modellezési kihívásra („a technológiai hatás gazdasági változókkal való kapcsolatának modellezése") a TFP blokkal összekapcsolt SCGE blokk ad megoldást a GMR rendszerben. A TFP blokkban a $\mathrm{K}+\mathrm{F}$, az emberi tőke, a nemzetközi tudáshálózati beágyazottság és a vállalkozás szintjének befolyásolását célzó szakpolitikai beavatkozások révén a regionális TFP-értékek nagysága megváltozik. Ennek a TFPváltozásnak a regionális input- és outputkeresletre és -kínálatra vagy az árakra gyakorolt hatásait az SCGE modellblokk becsüli meg.

A térbeli számszerüsített általános egyensúlyi (SCGE) modellek - Anthony Venables kifejezésével élve - az új gazdaságföldrajz „empirikus megfelelői” (Venables-Gasiorek [1999]). Szemléleti-módszertani gyökereiket tehát az új gazdaságföldrajzi (Krugman [1991], Fujita és szerzőtársai [1999]) és a számszerüsített általános egyensúlyi (CGE)

\footnotetext{
${ }^{4}$ Regionális vállalkozói és fejlesztési index (Regional Entrepreneurship and Development Index, REDI), lásd Szerb és szerzőtársai [2017].
} 
modellekben találjuk meg. A számszerüsített általános egyensúlyi (CGE) modellek a walrasi általános egyensúlyelmélet empirikus alkalmazásai gazdaságpolitikai hatáselemzésekre. A CGE modellek vonzó tulajdonsága, hogy a hatásoknak az egyes piacokon végigfutó (puszta logikai következtetésekkel nehezen átgondolható) láncolatait figyelembe véve vezetik le a beavatkozások várható eredményeit.

A térbeli számszerüsített egyensúlyi (SCGE) modellblokk tehát a tér dimenzióját adja hozzá az (általában egy területi egységre - jellemzően országokra - felépített) CGE modellekhez. Ez azt jelenti, hogy a területi egységek száma többszöröződik: az SCGE modellblokkban 181 régió viselkedését vizsgáljuk. Az egy területi egységre felépített CGE modellek további kiterjesztését az jelenti, hogy az SCGE blokkban beépítésre kerül az interregionális kereskedelem, a szállítási költségek, valamint megjelennek a (pozitív és negatív) agglomerációs hatások is, amelyek az elsődleges inputok (munka, tőke) áramlását is befolyásolják.

\section{A makroökomómiai (MACRO) blokk}

A harmadik és negyedik modellezési kihívásra („a növekedés tér-idő dinamikájának modellezése és a makrogazdasági hatások beépítése") az egymással összekapcsolt SCGE- és MACRO blokkok adnak feleletet. Az SCGE modellblokk a fejlesztéspolitikai beavatkozások térbeli dinamikáját írja le. E térbeli dinamikát a (szállítási költségen és a lakáspiaci telítettség szintjén keresztül érvényesülő) centrifugális és a (regionális TFP növekedésén keresztül ható) centripetális erők egymáshoz viszonyított nagyságai alakítják a termelési tényezők áramlásán keresztül addig, amíg a térbeli egyensúly ki nem alakul. Az idődimenziót tekintve az SCGE modell viszont statikus. A K + F-et és az emberi tőkét célzó beavatkozások TFP-re gyakorolt hatásainak időbeli dinamikája a TFP blokkban kiszámításra kerül ugyan, de a beavatkozások munkára és tőkére gyakorolt időbeli hatásai sem az SCGE, sem a TFP blokkban nem határozódnak meg. Az időbeli dinamika makroökonómiai blokkban való kiszámításának technikai oka éppen az, hogy ezt a bizonyos időbeli hatást a tökére és a munkára követni tudjuk.

A GMR-Európa modellben alkalmazott makroökonómiai blokkba az Európai Bizottság által kifejlesztett dinamikus és sztochasztikus általános egyensúlyi (Dynamic Stochastic General Equilibrium, DSGE) modellt, a QUEST III-at (Ratto és szerzötársai [2009]) építettük be.

\section{Modellintegrálás}

A három modellblokk komplex kölcsönös kapcsolatrendszerét a 2. ábra illusztrálja. Beavatkozások nélkül a TFP mind a regionális, mind a MACRO blokkokban azonos ütemben növekszik egy, a QUEST III által megbecsült rátát követve.

A modellblokkok kapcsolatrendszerét a TFP növekedését célzó szakpolitikai beavatkozások hatásainak bemutatása révén érzékeltetem, hat lépésben. 
2. ábra

A GMR-Európa modell felépítése

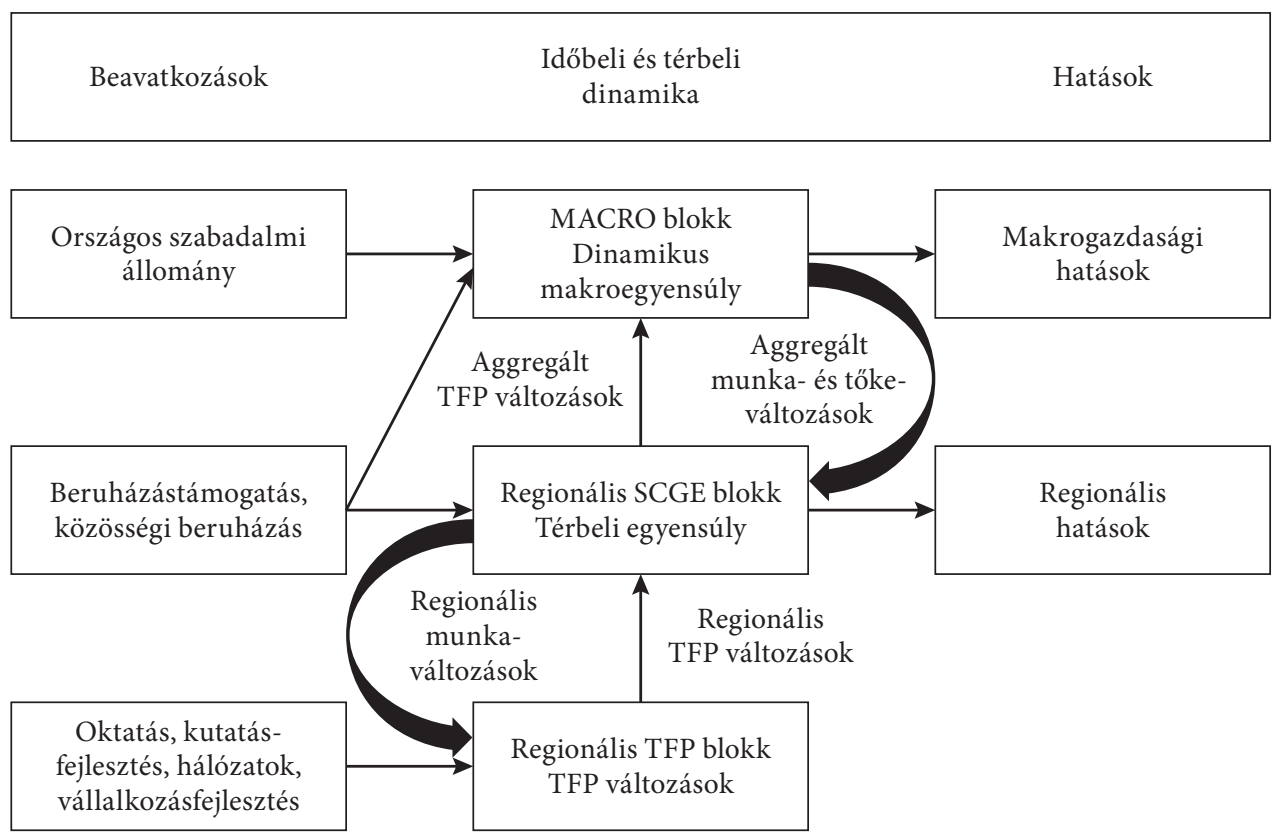

ELső LÉPÉs. A K +F, az emberi tőke, az interregionális tudáshálózatok és a vállalkozás szintjére ható beavatkozások eredményeképpen megváltozik a regionális TFP értéke a TFP blokkban.

MÁsOdik LÉPÉs. Az így megváltozott regionális TFP értékek átadódnak az SCGE modellblokknak, ahol a regionális termelékenység új nagyságai mellett kiszámolódnak a töke, a munka, az output és a kereslet mennyiségei, valamint a bérek, a tőkekamatok és a végső javak árai minden régióra és minden egyes időperiódusra. A hasznossági különbségek interregionális munkaerő- és tőkeáramlást eredményeznek, aminek következtében a regionális foglalkoztatottság változásai (a megnövekedett pozitív agglomerációs hatások révén) további változásokat indukálnak a regionális TFP értékekben is.

HARMADIK LÉPÉS. Az új regionális TFP értékek aggregálásra kerülnek minden egyes évre. Ezek a makro- (Európa-) szintü TFP értékek lépnek aztán be a MACRO modellbe mint időperiódus-specifikus sokkok. Ezen sokkok mellett a makroökonómiai modellblokkban kiszámításra kerülnek minden egyes időperiódusra a makroszintü változók aktuális értékei.

NEGYEDIK LÉPÉS. A beavatkozások eredményeként a MACRO modellben kiszámított tőke- és munkaerö-változások évenként szétosztásra kerülnek a régiók között a beavatkozások által indukált regionális TFP változások évenkénti térbeli mintáit követve.

ÖTÖDIK LÉPÉS. Az SCGE modellblokk újra fut az új tőke- és munkaerőértékekkel, hogy a mennyiségi és áregyensúlyokat újra kiszámítsa minden egyes régióra és minden egyes időperiódusra. 
HATOdiK LÉPÉs. Az esetek többségében az SCGE modellblokk regionális output, tőke, munka és lakossági fogyasztásainak aggregált értékei igen közel kerülnek a MACRO blokkban kiszámított értékekhez. Amennyiben ez mégsem lenne így, akkor a másodiktól az ötödik lépésig tartó folyamatok addig futnak, amíg az aggregált regionális értékek meg nem egyeznek a makroökonómiai blokkban kiszámított értékekkel.

\section{Szakpolitikai szimulációk - a vállalkozáspolitika és a hálózati politikák hatása különböző fejlettségü régiókban}

A GMR modelleket döntően a tudásalapú regionális fejlesztést célzó szakpolitikák gazdasági hatásainak elemzésére alkalmazzuk. Az utóbbi évek több projektjében az EU intelligens szakosodási politika (S3) hatáselemzési módszertanának kidolgozására és a modellszámítások alkalmazásaira helyezzük a hangsúlyt (Varga és szerzőtársai [2020a]). A szakpolitikusok nagy reményeket füznek a vállalkozás- és a hálózatfejlesztési beavatkozásokhoz az intelligens szakosodási politika megvalósítása során. A vállalkozáspolitikai beavatkozások a vállalkozói környezet fejlesztésében nyújthatnak segítséget, hiszen az S3 alapjául szolgáló „,vállalkozói felfedezés” folyamatához müködő vállalkozói ökoszisztéma szükséges (Szerb és szerzőtársai [2020]). A hálózati politika fontossága pedig azért merül fel, mert a régióban keletkezett innovatív ötletek továbbviteléhez sok esetben olyan tudásra van szükség, amely a régión kívül, fejlettebb innovációs rendszerekben állhat rendelkezésre. Az viszont nem mindig egyértelmü, hogy mely régióval - esetleg régiókkal - érdemes az innovációs kapcsolatokat fejleszteni, és az sem, hogy milyen mértékben. A külső kapcsolatok fejlesztése tehát szakpolitikai segítséget igényel (Olechnicka és szerzötársai [2019]).

A szakirodalom felhívja a figyelmet arra, hogy az innovációpolitikában nagyobb tapasztalatokkal rendelkezö, régebbi EU-tagállamok régiói eredményesebben alkalmazták az intelligens szakosodás politikáját (Capello-Kroll [2016], Veugelers [2015]), mint a kevéssé fejlett közép-európai régiók. Vajon az S3 által javallott vállalkozásfejlesztési és tudáshálózati politikák hatásai függnek-e attól, hogy milyen típusú régióban vezetik be őket? A fejlettebb vagy a kevéssé fejlett régiókban hatásosabb-e a vállalkozási politika vagy az innovációs hálózatok fejlesztése? E kérdések megválaszolása gazdasági modellszámításokkal támogatott szakpolitikai szimulációk felhasználásával lehetséges. A következőkben a GMR-Európa modell eredményeit elemezzük. ${ }^{5}$

Az elemzéshez hat, eltérő fejlettségi szinten álló európai régiót választottunk ki. Karlsruhe régió (DE12) magasan fejlett német iparosodott régió, ahol az S3 nem eredményezett nagy változásokat a regionális innovációs politikában. Drezda (DED2) posztszocialista német régió, fejlett innovációs rendszerrel, ahol az S3 alapjait sikeresen bevezették már az intelligens szakosodási politika európai megjelenése előtt. A lengyel Pomeránia régió (PL63) az ország egyetlen régiója, ahol az S3-at alulról felfelé történő építkezéssel müködtetik. Litvániát (LT00) az EU-alapoktól való nagyfokú függés és alacsony hatékonysággal müködő innovációs rendszer jellemzi, ahol az S3

\footnotetext{
${ }^{5}$ A további részleteket lásd Varga és szerzötársai [2020c].
} 
bevezetése nem hozott jelentős változásokat. Az Északkelet-Románia régió (RO21) az EU egyik legkevésbé fejlett régiója, amely komoly helyi kapacitáshiánnyal küzd a stratégia tervezése és megvalósítása terén. A magyar Dél-Dunántúl régió (HU23) alacsony szintű innovációs kapacitásokkal és iparosodottsággal, kevés tapasztalattal rendelkezik az S3 elveinek bevezetéséhez.

A vállalkozási környezet (a vállalkozói ökoszisztéma) fejlettsége alapján érzékelhető különbségek vannak a régiók között (3. ábra). Összehasonlításban mind a két német régió a legjobb teljesítményt mutatja, míg a közép-európai régióknak a vállalkozói ökoszisztémáját alacsonyabb REDI indexek jellemzik, különösen ÉszakkeletRománia és Dél-Dunántúl régiót.

3. ábra

A beavatkozások előtti REDI (bal oldal) és ENQ indexek értékei (jobb oldal) a kiválasztott régiókban, 2013 (100 pontos skálák)
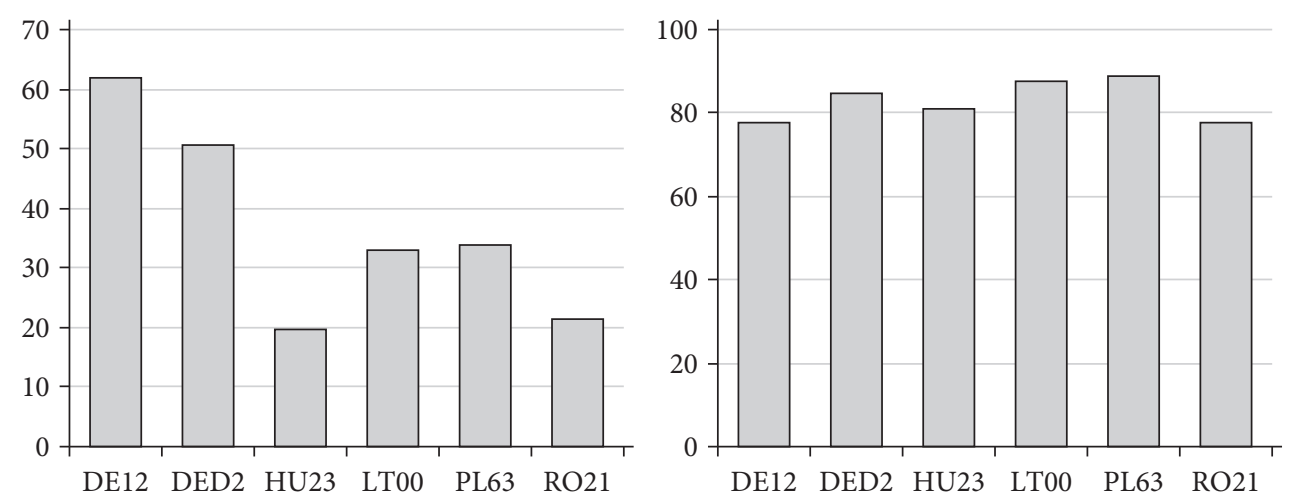

Rövidítések: DE12: Karlsruhe régió, DED2: Drezda, HU23: Dél-Dunántúl régió, LT00: Litvánia, PL63: Pomeránia régió, RO21: Északkelet-Románia régió.

Az ENQ index a régiók kutatási együttműködési hálózataiból elérhető tudásmennyiséget méri. Az EU-keretprogramok igen erősen összekapcsolt régiókat eredményeznek, ennek következtében a mintában szereplő régiók között viszonylag kis különbségek észlelhetök (3. ábra). Pomeránia (PL63), Drezda (DED2) és Litvánia (LT00) mutat átlag feletti hálózati beágyazottságot.

Szimulációink során 2014 és 2020 között mindegyik régióban fokozatosan tíz egységgel növeltük a vállalkozói ökoszisztémák rendelkezésére álló erőforrásokat. Ugyanebben az időszakban mindegyik régióban minden évben a kapcsolatok számát tízzel emeltük a régió tíz legerősebb partnerével. A beavatkozások REDI és ENQ hatásait a 4. ábra mutatja. A gazdasági hatásokat (amelyeket a regionális bruttó hozzáadott értékben történt változásokkal mérünk) a hat régió esetére az 5. ábra közli.

A vállalkozásfejlesztési beavatkozások azonos mértékủek, ám a gazdasági eredmények már nem azonosak. A vállalkozási politika hatásai több tényezőtől függnek a GMR modellekben, amelyek közül a regionális vállalkozói ökoszisztéma fejlettsége az egyik meghatározó faktor, az emberi tőke nagysága pedig a másik. A hatásmechanizmus megformálása során a vállalkozás tudástovaterjedés-alapú elméletét 
4. ábra

Az éves átlagos abszolút REDI (bal oldal) és ENQ (jobb oldal) változásai, 2014-2020
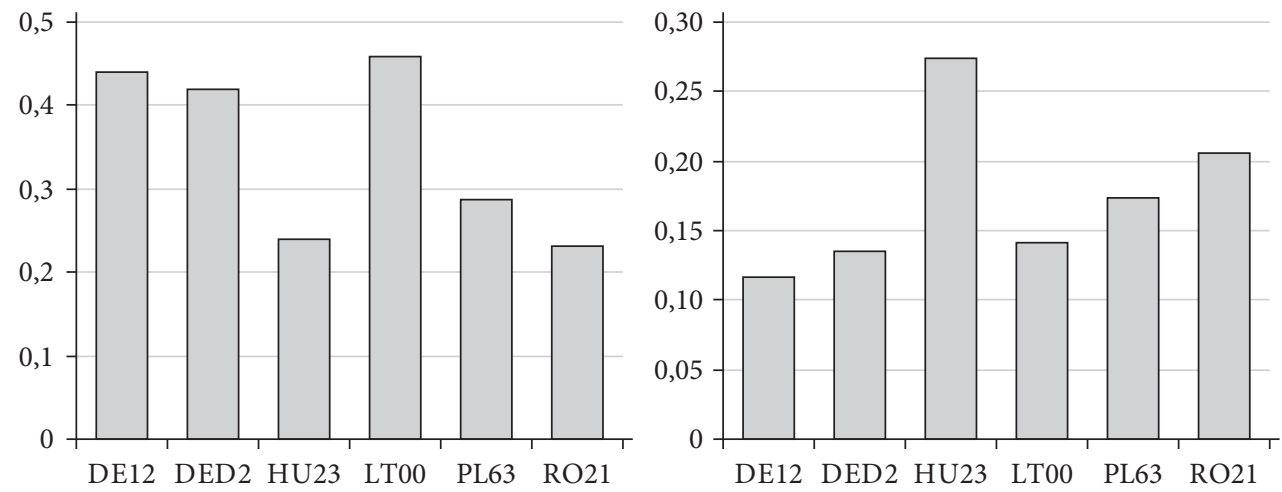

Rövidítések: DE12: Karlsruhe régió, DED2: Drezda, HU23: Dél-Dunántúl régió, LT00: Litvánia, PL63: Pomeránia régió, RO21: Északkelet-Románia régió.

követtük (Acs és szerzőtársai [2009]), amely azt állítja, hogy új, innovatív cégek révén áramlik át a vállalkozók birtokában levő tudás a gazdaságba. Ez az áramlás annál erősebb, minél fejlettebb a vállalkozói ökoszisztéma, és minél magasabb szintü a felhalmozott tudás a régióban. A 4. ábra jelzi, hogy a régiók között jelentős eltérés van a vállalkozói ökoszisztéma felszívóképességében. A fejlettebb vállalkozási környezetü régiók hatékonyabban használják fel a többleteröforrásokat. A gazdasági hatásokat elemezve (5. ábra) látható, hogy a fejlettebb regionális vállalkozói ökoszisztémával és magasabb emberitőke-kapacitással rendelkező német régióknál és Litvániában a legerősebb a hatás mind rövid, mind középtávon. Bár a román és a lengyel régió vállalkozási környezete hatékonyabban szívja fel az erőforrásokat, a magyar régió magasabb emberitöke-szintje következtében a gazdasági hatás ebben a régióban mégis némileg magasabb.

A hálózati politika hosszú távú gazdasági hatásait mutatja az 5. ábra jobb oldala. A hálózatok révén importált tudás felerősíti a kutatás-fejlesztés innovációs hatását, ami végül az új tudás magasabb regionális és országos készleteinek következtében növekvő termelékenységet és gazdasági hatást von maga után. Hasonlóan a vállalkozási politikához, a hálózatfejlesztési beavatkozások tekintetében is egyforma változások érik a hat régiót, a hatások szempontjából mégis különbségeket tapasztalunk. A felzárkózó régiók (Dél-Dunántúl régió, Litvánia, Pomeránia régió, Északkelet-Románia régió) a hálózatfejlesztés következtében több addicionális tudáshoz jutnak, hiszen ők az EU kutatási hálózataiban kevésbé központi helyeken állnak, így több terük van helyzetük javítására a tudásáramlásokban. Érdekes módon, bár a magyar régió a legtöbbet nyeri a tudáshálózatokból (4. ábra), a gazdasági hatás a régióban mégis közepes a többi régióhoz viszonyítva kevéssé fejlett $\mathrm{K}+\mathrm{F}$ infrastruktúrája következtében (5. ábra). A fejlettebb régiók kevesebb többlettudással gazdagodnak a beavatkozás nyomán, viszont kutatás-fejlesztési kapacitásaik jóval erősebbek, ennek következtében a hálózati politika gazdasági hatásaiban nincsenek jelentős eltérések a vizsgált régiók között. 


\section{5. ábra}

A vállalkozási (bal oldal) és a hálózati (jobb oldal) politika százalékos hatása a regionális bruttó hozzáadott értékre, 2014-2030
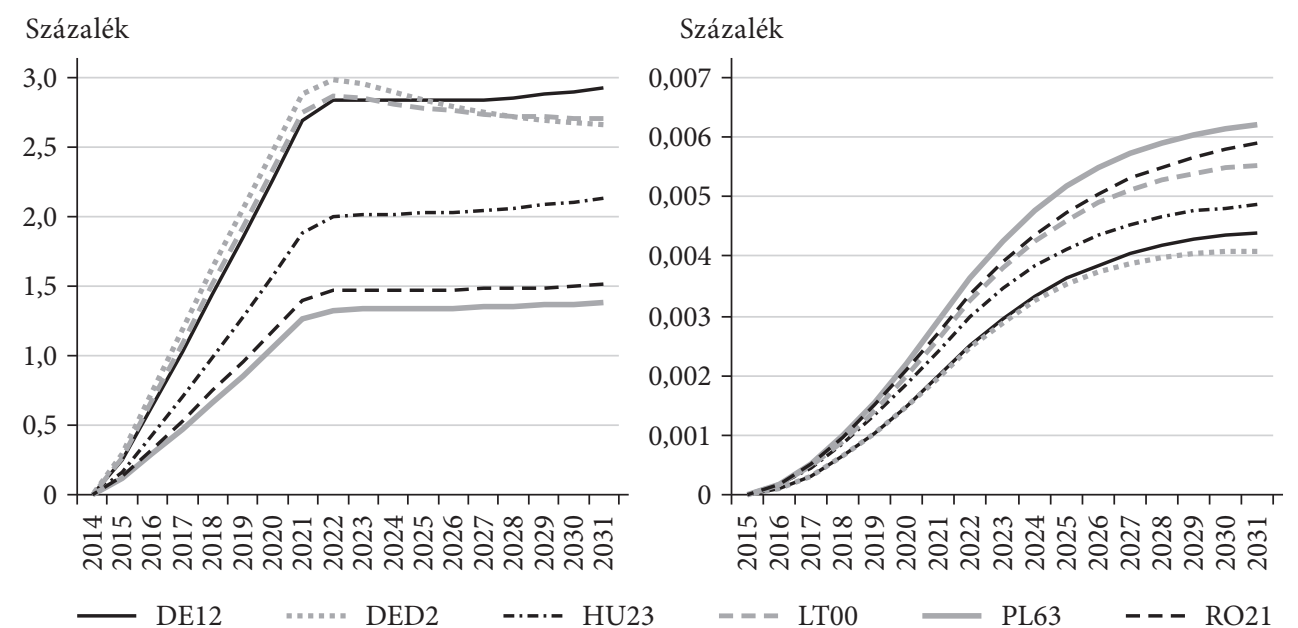

Röviditések: DE12: Karlsruhe régió, DED2: Drezda, HU23: Dél-Dunántúl régió, LT00: Litvánia, PL63: Pomeránia régió, RO21: Északkelet-Románia régió.

Elemzéseink szerint a regionális fejlettség befolyásolja a vállalkozási és a hálózati politikák gazdasági hatásait. A befolyás nagysága viszont beavatkozásspecifikus: jóval nagyobb a vállalkozási és kevéssé jelentős a hálózati politikák esetében. Vizsgálataink egyik fontos tanulsága az, hogy az intelligens szakosodást támogató szakpolitikák (például a $\mathrm{K}+\mathrm{F}$, az emberi tőke, az innovációs hálózati politikák vagy a vállalkozásfejlesztés) megtervezése során integrált szemlélet alkalmazása szükséges. A szakpolitikák hatásait nem külön-külön, hanem - azok kölcsönhatására tekintettel - együttesen kell elemezni. Ezeket a vizsgálatokat gazdasági modellek segítségével tudjuk elvégezni.

\section{Összegzés}

A tanulmányban a GMR hatáselemző modellrendszer elvi alapjait, felépítését és működését mutattam be egy, a modellek képességeit illusztráló szakpolitikai elemzés kíséretében. A GMR modellek úgy is interpretálhatók, mint a tudástermelési függvény vizsgálatainak kiterjesztései a regionális és a makrogazdasági elemzések irányába. A modellek így az innováció földrajzát a tudástermelési függvény segítségével elemző disszertációs kutatásaimra alapozódnak (Varga [1998]). A GMR modellek mögött meghúzódó elméleti építőköveknek (innovációs rendszerek, új gazdaságföldrajz, endogén növekedéselmélet) első összeillesztési kísérlete a 2000-es évek elején történt meg (Acs-Varga [2002]). Ebből nőtte ki magát a későbbiekben az empirikus modellrendszer.

A GMR modellek a modern fejlesztéspolitika által támasztott hatásmodellezési kihívásokra dolgoznak ki megoldásokat. A kihívások a térbeliségnek a hatáselemző modellekben való megjelenítésével, a regionális és az iparági dimenziók 
beépítésével és az utóbbi évtizedben megjelent új típusú beavatkozások (az innovációs hálózatpolitika vagy a regionális vállalkozáspolitika) hatáselemzésbe való integrálásával összefüggésben jelentek meg. A GMR modellek legújabb fejlesztései és alkalmazásai az innovációs politika új irányzatának, az intelligens szakosodásnak a hatáselemzését célozzák.

A feladat komplexitásából következően a GMR modellek fejlesztése szerteágazó tudásbázist igényel: az innováció földrajza, a vállalkozási ökoszisztémák és a gazdasági növekedés kutatásának bázisán létrejött új eredmények ugyanúgy szükségesek hozzá, mint a hatásmodellezés eszközrendszerének (ökonometriai, SCGE, DSGE, ágensalapú és rendszerdinamikai modellek) ismerete és napi szintű használata. A 2000-es évek közepétől a Pécsi Tudományegyetem Közgazdaságtudományi Kara Regionális Innováció- és Vállalkozáskutató Központjában fokozatosan fejlödött ki a modellek megalkotásához és alkalmazásához szükséges, nemzetközileg is egyedi tudáskombináció.

\section{Hivatkozások}

Acs J. Zoltan-Varga Attila [2002]: Geography, endogenous growth and innovation. International Regional Science Review, Vol. 25. 132-148. o. https://doi.org/10. 1177/016001702762039484.

Acs J. Zoltan-Varga Attila [2005]: Entrepreneurship, agglomeration and technological change. Small Business Economics, Vol. 24. 323-334. o. https://doi.org/10.1007/s11187005-1998-4.

Acs J. Zoltan-Audretsch, D.-Braunerhjelm, P.-Carlsson, B. [2009]: The knowledge spillover theory of entrepreneurship. Small Business Economics, Vol. 32. 15-30. o. https:// doi.org/10.1007/s11187-008-9157-3.

Aghion, P.-Howitt, P. [1998]: Endogenous growth theory. MIT Press, Cambridge.

Anselin, L.-VARGa AtTILA-Acs J. Zoltán [1997]: Local geographic spillovers between university research and high technology innovations. Journal of Urban Economics, Vol. 42. No. 3. 422-448. o. https://doi.org/10.1006/juec.1997.2032.

BALDWIN, R.-Martin, P. [2004]: Agglomeration and regional growth. Megjelent: Henderson, V. J.-Thisse, J.-F. (szerk.): Handbook of Regional and Urban Economics. Vol. 4. Cities and Geography. Elsevier, North-Holland, 2671-2711. o.

BarCA, F. [2009]: An Agenda for A Reformed Cohesion Policy. A Place-Based Approach to Meeting European Union Challenges and Expectations. Independent Report Prepared at the Request of the European Commissioner for Regional Policy, Danuta Hübner, European Commission, Brüsszel.

BAYAR, A. [2007]: Simulation of R\&D Investment Scenarios and Calibration of the Impact on a Set of Multi-Country Models. European Commission, DG JRC Institute for Prospective Technological Studies (IPTS).

Boschma, R. [2005]: Proximity and innovation: A critical assessment. Regional Studies, Vol. 39. No. 1. 61-74. o. https://doi.org/10.1080/0034340052000320887.

Bröcker, J.-Korzhenevych, A. [2011]: Forward Looking Dynamics in Spatial CGE Modelling. Institute for the World Economy, Kiel, Working Paper, No. 1731. 1-24. o.

CAPELlO, R. [2007]: A Forecasting Territorial Model of Regional Growth: the MASST Model. The Annals of Regional Science, Vol. 41. No. 4. 753-787. o. https://doi.org/10.1007/s00168007-0146-2. 
CAPello, R.-Kroll, H. [2016]: From theory to practice in smart specialization strategy: emerging limits and possible future trajectories. European Planning Studies, Vol. 24. No. 8. 1393-1406. o. https://doi.org/10.1080/09654313.2016.1156058.

D'Costa, S.-Garcilazo, E.-Oliveira Martins, J. [2013]: The Impact of Structural and Macroeconomic Factors on Regional Growth. OECD Regional Development Working Papers, No. 11.

ESRI [2002]: An Examination of the ex-post macroeconomic impacts of CSF 1994-1999 on Objective 1 countries and regions. Final Report, ESRI-GEFRA, Dublin, https://ec.europa. eu/regional_policy/sources/docgener/evaluation/doc/obj1/macro_modelling.pdf.

FAGiolo, G.-Dosi, G. [2003]: Exploitation, exploration and innovation in a model of endogenous growth with locally interacting agents. Structural Change and Economic Dynamics, Vol. 14. No. 3. 237-273. o. https://doi.org/10.1016/S0954-349X(03)00022-5.

Feldman, M.-Florida, R. [1994]: The Geographic Sources of Innovation: Technological Infrastructure and Product Innovation in the United States. Annals of the Association of American Geographers, Vol. 84. No. 2. 210-229. o. https://doi.org/10.1111/j.1467-8306.1994. tb01735.x.

Fujita, M.-Krugman, P.-Venables, A. [1999]: The Spatial Economy. MIT Press, Cambridge. Hermannsson, K.-Lisenkova, K.-Lecca, P.-McGregor, P.-Swales, K. [2010]: The Importance of Graduates for the Scottish Economy: A "Micro-to-Macro" Approach. Scottish Institute for Research in Economics, Discussion Paper, SIRE-DP-2010-80.

Ivanova, O.-Heyndrickx, C.-Spitaels, K.-Tavasszy, L.-Manshanden, W.-Snelder, M.Koops, O. [2007]: RAEM: version 3.0. Final Report. Transport \& Mobility Leuven, Leuven.

KRUGMAN, P. [1991]: Increasing returns and economic geography. Journal of Political Economy, Vol. 99. No. 3. 483-499. o.

OECD [2009]: How Regions Grow. OECD Publishing, Párizs.

Olechnicka, A.-PloszaJ, A.-Celinska-Jankowicz, D. [2019]: The geography of scientific collaboration. Routledge, London-New York.

PArtridge, M.-Rickman, D. [2010]: Computable General Equilibrium (CGE]: Modelling for Regional Economic Development Analysis. Regional Studies, Vol. 44. No. 10. 1311-1328. o. https://doi.org/10.1080/00343400701654236.

Ratto, M.-Roeger, W.-IN'T Veld, J. [2009]: QUEST III: An estimated open-economy DSGE model of the euro area with fiscal and monetary policy. Economic Modelling, Vol. 26. No. 1. 222-233. o. https://doi.org/101016/j.econmod.2008.06.014.

Romer, P. [1990]: Endogenous technological change. Journal of Political Economy, Vol. 98. No. 5. 71-102. o.

Saviotti, P.-Pyка, A. [2003]: Economic development, variety and employment. Working Paper, No. 35. Working Papers Series: Growth and Employment in Europe: Sustainability and Competitiveness. Vienna University of Economics and Business Administration, Bécs.

Schalk, H.-VARga Attila [2004]: The economic effects of EU Community Support Framework interventions. An ex-ante impact analysis with EcoRET, a macroeconomic model for Hungary. Center of Applied Economic Research Münster (CAWM), University of Münster, Münster.

Sebestyén TAmás-VARga Attilla [2013]: Research productivity and the quality of interregional knowledge networks. Annals of Regional Science, Vol. 51. No. 1. 155-189. o. https:// doi.org/10.1007/s00168-012-0545-x.

SMith, A. [1940]: Vizsgálódás a nemzetek jólétének természetéről és okairól. I-II. kötet. Fordította: Éber Ernő. Magyar Közgazdasági Társaság, Budapest. 
Szerb LÁszló-Vörös Zsófia-Komlósi Éva-Acs J. Zoltan-PÁger Balázs-Rappai GÁвоR [2017]: The Regional Entrepreneurship and Development Index: Structure, Data, Methodology and Policy Applications. FIRES research report. https://projectfires.eu/ wp-content/uploads/2018/02/D4.4-REVISED.pdf.

Szerb László-Ortega-Argilés, R.-Acs J. Zoltan-Komlósi Éva [2020]: Optimizing Entrepreneurial Development Processes for Smart Specialization in the European Union. Papers in Regional Science, megjelenés alatt.

VARGA AtTILA [1998]: University Research and Regional Innovation: A Spatial Econometric Analysis of Academic Knowledge Transfer. Kluwer Academic Publishers, Boston.

VARga Attila [2000]: Local academic knowledge spillovers and the concentration of economic activity. Journal of Regional Science, Vol. 40. 289-309. o. https://doi.org/10. 1111/0022-4146.00175.

VARGa AtTila [2006]: The spatial dimension of innovation and growth: Empirical research methodology and policy analysis. European Planning Studies, Vol. 9. 1171-1186. o. https:// doi.org/10.1080/09654310600933298.

VArga Attila [2009]: Térszerkezet és gazdasági növekedés. Akadémiai Kiadó, Budapest. VARGA AtTila [2016]: Regionális fejlesztéspolitikai hatáselemzés. Innováció, vállalkozás és gazdasági növekedés a GMR Európa modellben. Akadémiai Kiadó, Budapest.

VARga Attila [2017]: Place-based, Spatially Blind, or Both? Challenges in Estimating the Impacts of Modern Development Policies: The Case of the GMR Policy Impact Modeling Approach. International Regional Science Review, Vol. 40. No. 1. 12-37. o. https://doi. org/10.1177/0160017615571587.

VARGa Attila [2019]: Földrajzi, makro- és regionális gazdasági hatáselemzés. Megjelent: Faragó László (szerk.): Kortárs térelméletek kelet-közép-európai kontextusban. Dialóg Campus Kiadó, Budapest, 123-139. o.

Varga Attila-Baypinar, M. [2016]: Economic impact assessment of alternative European Neighborhood Policy (ENP) options with the application of the GMR Turkey model. Annals of Regional Science, Vol. 56. 153-176. o. https://doi.org/10.1007/s00168015-0725-6.

Varga Attila-Horváth Márton [2015]: Regional knowledge production function analysis. Megjelent: Anderson, M.-Karlsson, C. (szerk): Handbook of Research Methods and Applications in Economic Geography. Edward Elgar Publishers, CheltenhamNorthampton, 513-537. o.

Varga Attila-Járosi Péter-Sebestyén Tamás [2013]: A 2014-2020 közötti időszak ex ante értékeléséhez: a támogatások várható makrogazdasági hatásainak modellezése. Nemzeti Fejlesztési Ügynökség, NFÜ 30/2013. számú projekt.

Varga Attila-Pontikakis, D.-Chorafakis, G. [2014]: Metropolitan Edison and cosmopolitan Pasteur? Agglomeration and interregional research network effects on European R\&D productivity. Journal of Economic Geography, Vol. 14. No. 2. 229-263. o. https://doi. org/10.1093/jeg/lbs041.

Varga Attila-Sebestyén Tamás-Szabó Norbert-Szerb László [2018]: Economic Impact assessment of Entrepreneurship policies with the GMR-Europe Model. FIRES Deliverable 4.6., D4.6 GMR model for Europe linking Entrepreneurship, Institutions and Growth. https://projectfires.eu/wp-content/uploads/2018/05/p.2-d4.6-gmr-report.pdf.

Varga Attila-Szabó Norbert-Sebestyén Tamás [2020a]: Economic Impact Modeling of Smart Specialization Policy. Which Industries should Prioritization Target? Papers in Regional Science (megjelenés alatt). 
Varga Attila-Szabó Norbert-Sebestyén Tamás-Farkas Richárd-Szerb LászlóKomlósi Éva-Járosi PÉter-Andor Krisztina-CsAjkÁs Anna [2020b]: The GMR Hungary multiregion - multisector economic impact model. RIERC Research Report, 2020-01. Regional Innovation and Entrepreneurship Research Center, Faculty of Business and Economics, University of Pécs, http://hu.rierc.ktk.pte.hu/sites/default/files/pdf/The\%20GMR_ HU\%20multisector-multiregion\%20model.pdf.

Varga Attila-Sebestyén Tamás-Szabó Norbert-Szerb László [2020c]: Estimating the economic impacts of knowledge network and entrepreneurship development in smart specialization policy. Regional Studies, Vol. 54. No. 1. 48-59. o. https://doi.org/10.1080/0 0343404.2018.1527026.

Venables, A. J.-GasioreK, M. [1999]: The Socio-Economic Impact of Projects Financed by the Cohesion Fund. A Modeling Approach. European Commission, Luxembourg.

Veugelers, R. [2015]: Do we have the right kind of diversity in Innovation Policies among EU Member States? WWWforEurope Working Paper, No. 108.

World BAnk [2009]: World Development Report, 2009. Reshaping Economic Geography. World Bank, Washington, DC. 